\title{
Symbiotic microencapsulation to enhance Bifidobacterium longum and Lactobacillus paracasei survival in goat cheese
}

\author{
Nazan KAVAS ${ }^{1 *}$ (D), Gökhan KAVAS², Özer KINIK², Mustafa ATEŞ3, Muammer KAPLAN ${ }^{4}$, Gülçin ŞATIR ${ }^{5}$
}

\begin{abstract}
In the study, the microencapsulation method was applied in the production of white cheese from goat milk to prevent the loss of viability of Lactobacillus paracasei and Bifidobacterium longum due to environmental factors during their storage period. For this purpose, the cheese was obtained using three types of microcapsules - symbiotic microcapsules containing probiotic bacteria and probiotic + fructooligosaccharide, probiotic + inulin. In addition, probiotics, fructooligosaccharide and inulin have been added to cheese in free form, and a total of 7 different cheeses have been produced with the control sample. In the microencapsulation, $1 \%$ sodium alginate was used as coating material and the extrusion method was applied. The cheese samples have been stored at $+4{ }^{\circ} \mathrm{C}$ for 180 days. It has been determined that the viability of $L$. paracase $i$ and B.longum has been preserved with the microencapsulation technique, while the viability of probiotic bacteria is preserved at a higher level in cheese samples obtained with the addition of prebiotics to microencapsules. It has been concluded that probiotic microorganisms are available above the minimum therapeutic effect value in grams of cheese samples containing microcapsules and these cheese could be considered as probiotic.
\end{abstract}

Keywords: symbiotic microcapsules; Bifidobacterium longum; Lactobacillus casei; goat cheese; viability.

Practical Application: Microencapsulation technique used in our study significantly increases the viability levels of probiotic microorganisms in goat cheese.

\section{Introduction}

The importance given to goat milk and its products, which are distinguished technologically from cow and sheep milk and are economically more valuable because of their different taste, aroma and quality, has been recently increased. Goat milk is mostly used in cheese production among dairy products (Ranadheera et al., 2018, 2019; Herman-Lara et al., 2019; Lucatto et al., 2020). Probiotic microorganisms are considered as functional food components that have positive effects on human health (Guarner, 2017). Prebiotics, which are defined as non-digestible food ingredients, which positively affect human health by promoting the development and activity of beneficial bacteria in the large intestine, have been the source of many studies on the development of new fermented dairy products in the dairy industry. As a result of the symbiotic products produced by using probiotics and prebiotics together, the beneficial effects of probiotics on human health are supported by prebiotics. If probiotic microorganisms are consumed together with prebiotics, they can stay viable longer and provide more benefits for metabolism (Sanders et al., 2018). Although the studies conducted on the physiological effects of probiotic microorganisms have determined that the dose required for

the preventive effect against diarrhea, lactose intolerance and colon cancer is $10^{9}-10^{10} \mathrm{cfu} / \mathrm{g}$, the International Dairy Federation (IDF) has reported this rate as a minimum of $10^{7} \mathrm{cfu} / \mathrm{g}$ live cells and has stated that foods defined as probiotic should contain at least the specified ratio of live bacteria (International Dairy Federation, 2008; Guarner, 2017).

In recent years, the microencapsulation method has been applied in order to increase the viability of probiotic microorganisms and to prevent the product from being affected by the compounds formed during the storage process (Rezaei et al., 2019; Menezes et al., 2019; Pivetta et al., 2020). Microencapsulation is defined as "[...] the coating of solid, liquid or gaseous materials as micro particles with a protein or carbohydrate-based material or both selected as coating material" (Čakarević et al., 2020). In recent studies, symbiotic microcapsules have been studied by adding prebiotics to the coating material during microencapsulation in order to increase probiotic viability and success has been achieved in this field. For this purpose, the studies have widely used prebiotics such as fructooligosaccharide, inulin, Hi-maize starch, isomaltooligosaccharides (Shori et al., 2018). In the light 
of these information, the study has aimed to obtain Symbiotic microcapsules by adding prebiotics (fructooligosaccharide and inulin) to the coating material, which encourage the viability and development of probiotic bacteria, and consequently to increase the viability of probiotic bacteria. Besides, with the addition of probiotic bacteria, microencapsulated probiotic bacteria and prebiotics to cheese in free form, the study has aimed to add microencapsulated symbiotic microcapsules to goat cheese separately and to compare the viability of cheese during production and storage.

\section{Materials and methods}

Goat milk cheese has been produced at Şemsi İgi Food product Ltd. Şti. (Pınarbaşı, Izmir, Turkey). Lactococcuslactis ssp. lactis + Lactococcuslactis ssp. cremoris (Mayasan-Sacco) as rennet and Lafti B22 Bifidobacterium longum (B.longum) and Lafti L26 Lactobacillus paracasei (L.paracasei) (DSM) as probiotic microorganisms (ratio in the mixture: 50\%) have been used. Sodium alginate ( $1 \%$ solution) from natural polymers has been used in microencapsulation. In addition, $1 \%$ peptides (pancreatic digestible casein) have been added to promote the growth with fructooligosaccharide as a prebiotic into microcapsules, and 0.1 $\mathrm{M} \mathrm{CaCl}_{2}$ solution has been used as hardening agent.

\subsection{Activation of cheese cultures}

Cultures in lyophilised (freeze-dried) form transferred to MRS broth (Fluka Chemie GmbH, Buchs, Switzerland) under aseptic conditions have been reproduced at $37^{\circ} \mathrm{C}$ and activated at least twice. Following the activation process, the cultures have been incubated at $37^{\circ} \mathrm{C}$ for 1 night under anaerobic conditions within milk, which have been prepared from skimmed milk powder with $12 \%(\mathrm{w} / \mathrm{v})$ dry matter and sterilized at $110^{\circ} \mathrm{C}$ for 15 minutes. Then, they have been used in the cheese extractions. Before using the microorganisms in cheese production, the count of bacteria per $\mathrm{mL}$ of the cultures has been determined.

\subsection{Preparation of probiotic microorganism cultures}

In order to obtain probiotic bacteria in a certain number before microencapsulation and to prepare cell suspension, B.longum has been passaged to MRS broth containing $0.05 \%$ L-cysteine hydrochloride and incubated at $37^{\circ} \mathrm{C}$ for 3 days under anaerobic conditions, and $L$.paracase $i$ has been passaged to MRS broth (Fluka Chemie GmbH, Buchs, Switzerland) and incubated a $37^{\circ} \mathrm{C}$ for 2 days under anaerobic conditions. This procedure has been performed 2 times. Following the incubation, the cultures centrifugated at $3000 \mathrm{xg} 4{ }^{\circ} \mathrm{C}^{\prime}$ for 15 minutes have been washed in sterile peptone $(0.1 \mathrm{~g} / 100 \mathrm{~g})$ solution or saline solution. The final concentration of probiotic microorganisms has been set to be a minimum of $10^{9} / \mathrm{mL}$.

\subsection{Microencapsulation of probiotic microorganisms}

Microcapsules have been prepared using the extrusion method in 3 different types. In this method, for Type 1 microcapsule extraction, $1 \%$ of probiotic culture mixture (L. paracasei + B. longum) concentrate has been pre-autoclaved (for 15 minutes at $121^{\circ} \mathrm{C}$ ) and mixed with $1 \%$ sodium alginate.
For Type 2 microcapsule extraction, fructooligosaccharide (FOS) has been added to the Na-alginate + culture mixture. For Type 3 microcapsule extraction, inulin has been added to the Naalginate + culture mixture. The most efficient FOS and inulin ratio, determined by Chen et al. (2005) was taken as reference, and the rate of prebiotics to be added was determined to be $2 \%$ in the preliminary trial. In addition, $1 \%$ digestible autoclaved pancreatic casein has been added to improve the development of probiotics. The resulting mixture has been slowly dropped into sterile $0.1 \mathrm{M} \mathrm{CaCl}_{2}$ solution using injectors to obtain microcapsules. The distance between the recommended needle tip and the beaker where the $\mathrm{CaCl}_{2}$ solution is found $(10 \mathrm{~cm})$ has been taken into consideration (Chen et al., 2006). After waiting for gelification process for 1 hour, the capsules were stored in a sterile $0.1 \%$ peptone solution at $4{ }^{\circ} \mathrm{C}$.

\subsection{Cheese production}

In the cheese production process, goat milk was pasteurized at $75^{\circ} \mathrm{C}$ for 15 seconds, cooled to $36^{\circ} \mathrm{C}$ and divided into seven equal groups. In each group, $0.5 \%$ cheese culture, prepared from $0.01 \% \mathrm{CaCl}_{2}$ and sterilized skimmed milk powder and activated in milk was added. The cheese with SHPK code has been produced by adding the probiotic cultures (1\%) (L paracasei and B. longum, 1/1) in cheese milk at $35-37^{\circ} \mathrm{C}$ for the production of cheese containing probiotic culture in free form; The cheese with $\mathrm{SHPK}+\mathrm{F}$ code has been produced by adding $2 \%$ FOS as well as the probiotic cultures for the production of prebioticadded cheese; The cheese with SHPK + I code has been produced by adding $2 \%$ inulin as well as the probiotic cultures; The cheese with MKP code has been produced by adding only probiotic culture microencapsulated with alginate (1\%); The cheese with $\mathrm{MKP}+\mathrm{F}$ code has been produced by adding microcapsules containing FOSs as well as alginate as coating material, and the cheese with MKP+I code has been produced by adding microcapsules containing inulin as well as alginate as coating material. K-coded cheese is traditional cheese which is obtained with no probiotic culture additives.

Following the addition of probiotics and prebiotics, the milk has been added with rennet, coagulated and pressured. The cheese clots have been kept under pressure for approximately 90 minutes. After releasing the pressure and cutting, they were kept in $15 \%(\mathrm{w} / \mathrm{v})$ pasteurized brine for approximately 180 minutes. The cheese samples have been subjected to preripening in the cases until the $\mathrm{pH}$ value is approximately 5.05.1 , and have been packaged under vacuum in $0.5 \mathrm{~kg}$ units. The containers have been subjected to ripening for 180 days at $4 \pm 1{ }^{\circ} \mathrm{C}$. The microbiological analyzes have been performed to examine the viability of probiotic bacteria at days $1,15,30,45$, $60,75,90,120,150$ and 180.

\subsection{Determination of the position of microcapsules in the cheese matrix}

The microcapsules obtained in the research were added to the milk before the fermentation process, and their positions in the cheese matrix have been determined on the first day and in certain periods of the ripening period. The cheese samples cut 
in the size of 4-5 $\mathrm{mm}^{3}$ have been kept in $2.8 \% \mathrm{w} / \mathrm{v}$ glutaraldehyde solution for 1 day and washed with distilled water, and this procedure has been repeated 10 times. Following 2 additional fixation procedures for 30 and 60 minutes, the samples have been kept in $20 \%, 40 \%, 60 \%, 80 \%, 95 \%$ and $100 \%$ ethanol solution for at least 2 hours and oil has been extracted from them using chloroform solution at intervals of 15 minutes, and the cheese samples have been stored at $-18{ }^{\circ} \mathrm{C}$ until analyzed (Sipahioğlu et al., 1999). The positions of the samples in the cheese matrix have been determined using Hitachi TV 1000 Table Top Microscope (Japan).

\subsection{Probiotic microorganisms and cheese culture count}

The B.longum count was measured in NPNL-MRS agar medium containing nalidixic acid, paromycin sulfate, neomycin sulfate and lithium chloride as inhibitory agents. After placing on the petri plates, the NPNL mixture, sterilized using a $0.45 \mu \mathrm{m}$ single-use sterile filter (Sartorius Minisart ${ }^{\circledR}$ - Sartorius AG, Goettingen, Germany), in an amount of $20 \%$ (volume/ volume) in the final composition of the medium has been added to sterile MRS agar (Merck KGaA, Darmstadt, Germany) medium. The petri plates have been incubated in anaerobic jars (Merck KGaA, Darmstadt, Germany) for 72 hours at $37^{\circ} \mathrm{C}$. The anaerobic medium was ensured using Anaerocult ${ }^{\circ}$ A (Merck KGaA, Darmstadt, Germany) anaerobic kits. The L. paracasei count has been performed using the MRS agar (Merck KGaA, Darmstadt, Germany) growth medium (Gardiner et al., 2002). The samples have been incubated at $37^{\circ} \mathrm{C}$ for 72 hours under anaerobic conditions. The Lactococcus (used as a starter culture) count has been performed using M 17 agar (Merck KGaA, Darmstadt, Germany) medium. The samples have been incubated at $37^{\circ} \mathrm{C}$ for 48 hours.

\subsection{Statistical analysis}

Cheese samples were studied with two replications and three parallels, and the analysis of variance (ANOVA) was performed. The data were analyzed using SPSS version 15 . Data from ANOVA were considered significant at $p<0.05$ level based on the Duncan's multiple comparison test.

\section{Results and discussion}

\subsection{The appearance of probiotic microcapsules and symbiotic microcapsules obtained by extrusion method in cheese mass}

In our study, there was no difference between the culture type and microencapsulation method in terms of matrix structure of the cheese produced. Although the observed matrix structure showed slight differences during the storage period depending on the saline ratio, storage temperature and the water ratio in the mass, the mass maintained the matrix structure in which the casein micelles and its other components are being bound (Fangmeier et al., 2019). In cheese samples to which probiotic bacteria have been added in free form, it has been determined that they attach to the outer surfaces of the matrix, and microcapsules containing probiotic bacteria are capsular in the matrix structure
(Figure 1). Similar results have been obtained in the studies by Madureira et al. (2005) and Rama et al. (2020).

\subsection{Viability of Lactobacillus paracasei used as probiotic in cheese during the ripening period}

The change of viability of $L$. paracase $i$ in probiotic culture, prebiotic + probiotic culture, microencapsulated probiotic culture and goat cheese produced using symbiotic microcapsules during the ripening period has been given in Table 1 .

The cheese sample with the highest viability on average during 180-day ripening period of $L$. paracasei was $\mathrm{MKP}+\mathrm{F}$, followed by MKP+I, MKP, SHPK+F, SHPK+I and SHPK cheese samples. The statistical analysis has shown that the viability of L. paracasei during 180 -day ripening period was insignificant ( $p>0.05$ ) in the SHPK, SHPK+F and SHPK+I samples, but the difference of these samples from the MKP, MKP+F and MKP+I samples was significant $(\mathrm{p}<0.05)$.

The decrease in the count of probiotic bacteria in the cheese matrix during the ripening period has been obtained in similar studies as well. It has been stated that the main reason for this was associated with the increase in saline concentration in the cheese matrix during the ripening period (Castro et al., 2015; Evangelia et al., 2016; Moraes et al., 2018).

A study examining the viability of $L$. paracasei NFBC 338 strain in cheddar cheese during a 6-month ripening period has reported that the viability of the bacterium is at a high level and the relevant bacterium maintains its viability at the level of $10^{8} \mathrm{cfu} / \mathrm{g}$ during the ripening period (Gardiner et al., 2002).

In the MKP cheese samples containing microencapsulated $L$. paracasei, the count of $L$. paracase $i$ has decreased from $10.36 \log _{10} \mathrm{cfu} / \mathrm{g}$ at the beginning to $9.75 \log _{10} \mathrm{cfu} / \mathrm{g}$ at the end of day 180. In the SHPK cheese samples added with $L$. paracasei in free form, the bacteria count has decreased to $6,59 \log _{10} \mathrm{cfu} / \mathrm{g}$ at the end of 180-day ripening period, and in the MKP cheese samples containing microencapsulated L.paracasei, this count was higher. In addition, the count of $L$.paracase in the $\mathrm{MKP}+\mathrm{F}$ and MKP+I cheese samples at the end of ripening period was higher in MKP cheese samples. According to these data, it has been determined that the viability of probiotic bacteria is preserved at a higher level in cheese samples obtained with the addition of inulin and FOS to microencapsules. Another study on the effect of alginate concentration varying between $1 \%$ and $3 \%$ used in the production of probiotic microencapsules containing L.acidophilus and L.casei on the viability of the probiotic bacteria has reported that the alginate concentrations have no effect, but the viability of microencapsules with FOS, isomaltooligosaccharide and peptide together with L. acidophilus and L.casei could be highly preserved (Chen et al., 2005).

A study examining the viability of W.paramesenteroides, L. paraplantarum, E. faecalis and L. plantarum microencapsulated with arrowroot starch has determined that the microencapsulation technique had positive effects on the viability (Samedi \& Charles, 2019). In the light of these data, our results are consistent with the literature (Chaudhary \& Patel, 2019). 

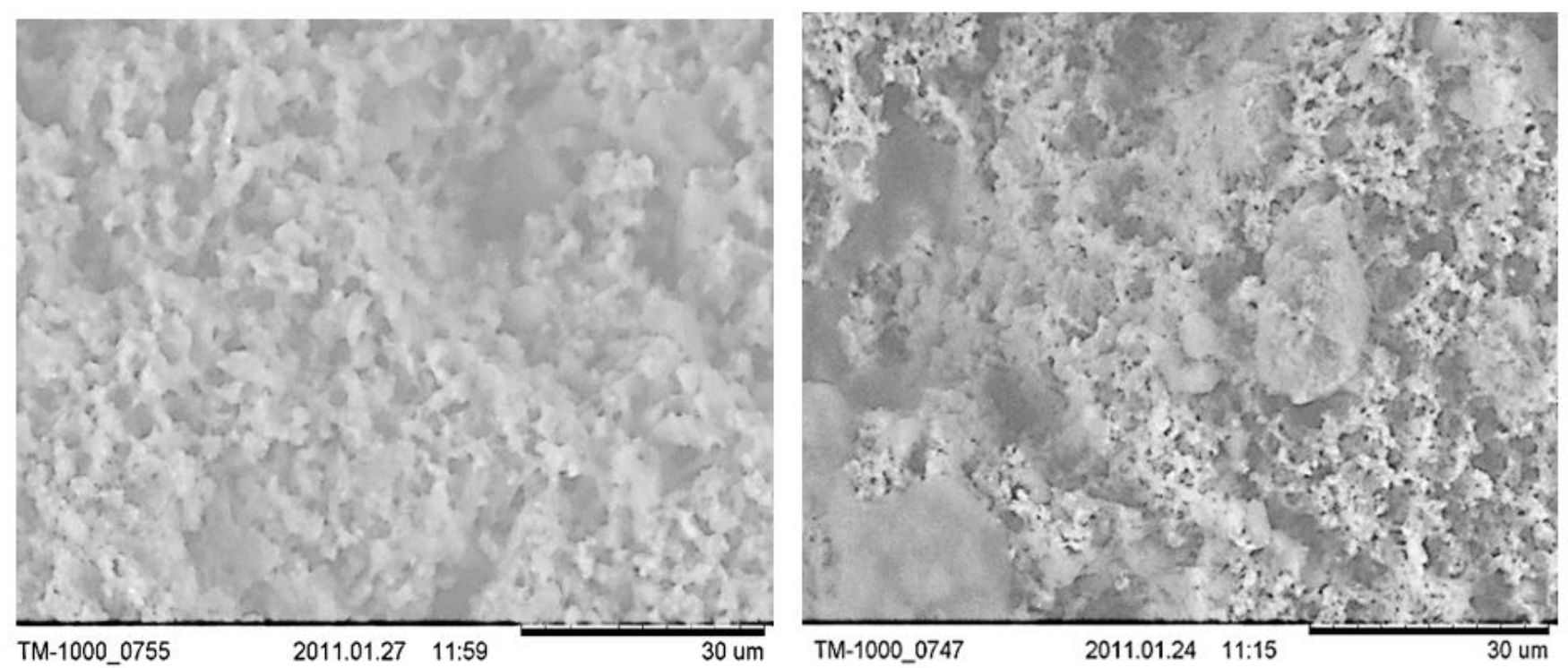

A

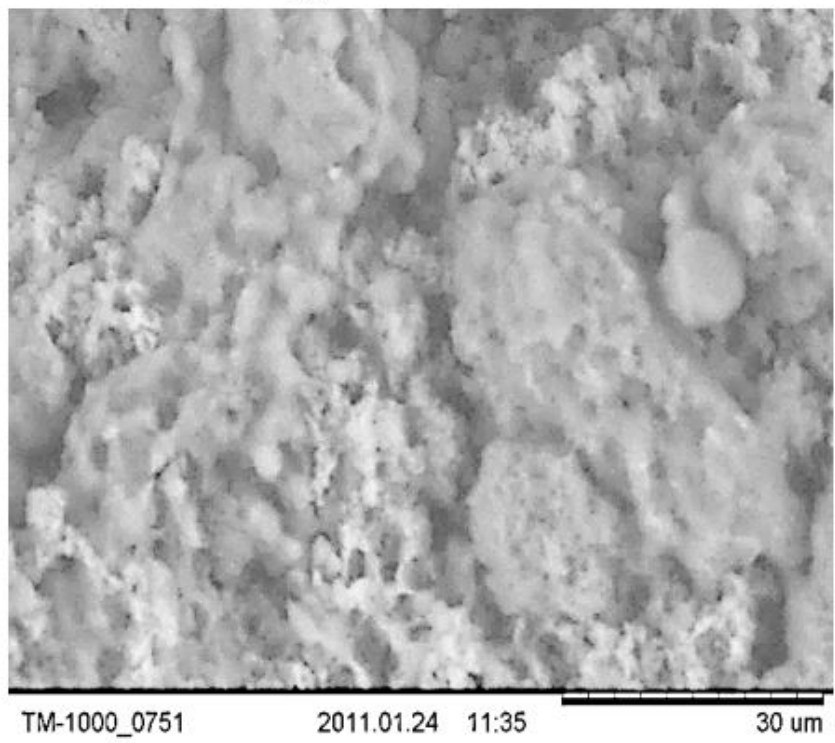

\section{B}

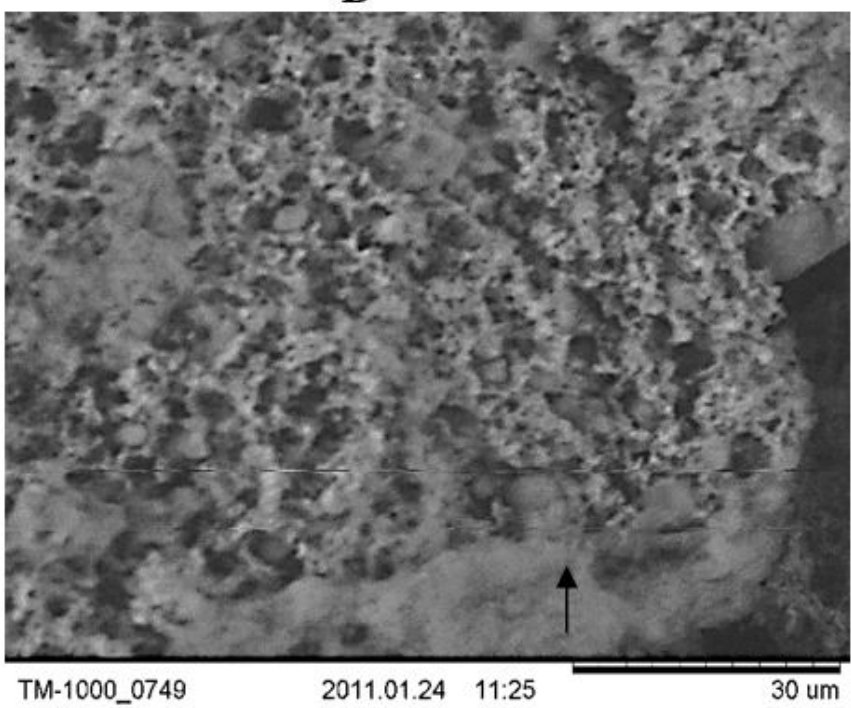

C

D

Figure 1. Appearance of some cheese matrices with Scanning Electron Microscope. (A) Appearance of probiotic bacteria in SHPK cheese sample; (B) Appearance of microcapsules in MKP cheese sample; (C) Appearance of microcapsules in MKP+F cheese sample; (D) Appearance of microcapsules in $\mathrm{MKP}+\mathrm{I}$ cheese sample.

\subsection{Viability of Bifidobacteriumlongum (B.longum) used as probiotic in cheese during the ripening period}

The change of viability of B.longum in probiotic culture, prebiotic + probiotic culture, microencapsulated probiotic culture and goat cheese produced using symbiotic microcapsules during the ripening period has been given in Table 2. As can be seen in the Table 2 , the cheese sample with the highest viability on average during 180-day ripening period of $B$. longum was $\mathrm{MKP}+\mathrm{F}$, and the lowest one was SHPK. The statistical analysis has shown that the viability of B.longum during 180-day ripening period was insignificant $(\mathrm{p}>0.05)$ in the SHPK, SHPK $+\mathrm{F}$ and SHPK+-I samples, but the difference of these samples from the $\mathrm{MKP}, \mathrm{MKP}+\mathrm{F}$ and $\mathrm{MKP}+\mathrm{I}$ samples was significant $(\mathrm{p}<0.05)$. The effect of ripening time on cheese samples was found to be significant in the SHPK cheese sample after Day 75, in the 
Table 1. Changes in the number of Lactobacillus paracasei in cheese samples during ripening $\log _{10}$ (cfu/g).

\begin{tabular}{clllllc}
\hline Days/ Samples & SHPK & SHPK $+\mathrm{F}$ & SHPK+I & MKP & MKP+F & MKP+I \\
\hline 1 & $9.30 \pm 0.09 \mathrm{a}^{\mathrm{A}}$ & $9.34 \pm 1.13 \mathrm{a}^{\mathrm{A}}$ & $9.32 \pm 0.47 \mathrm{a}^{\mathrm{A}}$ & $10.36 \pm 0.05 \mathrm{~b}^{\mathrm{A}}$ & $10.46 \pm 1.10 \mathrm{c}^{\mathrm{A}}$ & $10.45 \pm 2.21 \mathrm{c}^{\mathrm{A}}$ \\
15 & $9.26 \pm 0.14 \mathrm{a}^{\mathrm{A}}$ & $9.31 \pm 1.45 \mathrm{a}^{\mathrm{A}}$ & $9.30 \pm 0.26 \mathrm{a}^{\mathrm{A}}$ & $10.34 \pm 0.02 \mathrm{~b}^{\mathrm{A}}$ & $10.43 \pm 1.23 \mathrm{c}^{\mathrm{A}}$ & $10.44 \pm 1.87 \mathrm{c}^{\mathrm{A}}$ \\
30 & $9.17 \pm 0.12 \mathrm{a}^{\mathrm{A}}$ & $9.26 \pm 1.20 \mathrm{a}^{\mathrm{A}}$ & $9.27 \pm 0.86 \mathrm{a}^{\mathrm{A}}$ & $10.32 \pm 0.12 \mathrm{~b}^{\mathrm{A}}$ & $10.39 \pm 1.45 \mathrm{c}^{\mathrm{A}}$ & $10.39 \pm 1.96 \mathrm{c}^{\mathrm{A}}$ \\
45 & $9.09 \pm 0.06 \mathrm{a}^{\mathrm{A}}$ & $9.23 \pm 1.71 \mathrm{a}^{\mathrm{A}}$ & $9.23 \pm 0.41 \mathrm{a}^{\mathrm{A}}$ & $10.31 \pm 0.14 \mathrm{~b}^{\mathrm{A}}$ & $10.37 \pm 1.86 \mathrm{c}^{\mathrm{A}}$ & $10.37 \pm 0.56 \mathrm{c}^{\mathrm{A}}$ \\
60 & $9.05 \pm 0.03 \mathrm{a}^{\mathrm{A}}$ & $9.18 \pm 1.33 \mathrm{a}^{\mathrm{A}}$ & $9.19 \pm 0.44 \mathrm{a}^{\mathrm{A}}$ & $10.34 \pm 0.44 \mathrm{~b}^{\mathrm{A}}$ & $10.351 .74 \mathrm{c}^{\mathrm{A}}$ & $10.35 \pm 0.78 \mathrm{c}^{\mathrm{A}}$ \\
75 & $8.91 \pm 0.01 \mathrm{a}^{\mathrm{A}}$ & $9.03 \pm 1.46 \mathrm{a}^{\mathrm{A}}$ & $9.04 \pm 0.70 \mathrm{a}^{\mathrm{A}}$ & $10.17 \pm 0.57 \mathrm{~b}^{\mathrm{A}}$ & $10.32 \pm 1.31 \mathrm{c}^{\mathrm{A}}$ & $10.32 \pm 0.26 \mathrm{c}^{\mathrm{A}}$ \\
90 & $8.78 \pm 0.08 \mathrm{a}^{\mathrm{B}}$ & $8.53 \pm 1.52 \mathrm{a}^{\mathrm{B}}$ & $8.51 \pm 0.39 \mathrm{a}^{\mathrm{B}}$ & $10.03 \pm 0.66 \mathrm{~b}^{\mathrm{A}}$ & $10.23 \pm 1.42 \mathrm{c}^{\mathrm{A}}$ & $10.22 \pm 1.68 \mathrm{c}^{\mathrm{A}}$ \\
120 & $8.53 \pm 0.11 \mathrm{a}^{\mathrm{B}}$ & $8.51 \pm 1.86 \mathrm{a}^{\mathrm{B}}$ & $8.51 \pm 0.82 \mathrm{a}^{\mathrm{B}}$ & $10.03 \pm 0.41 \mathrm{~b}^{\mathrm{A}}$ & $10.23 \pm 0.13 \mathrm{c}^{\mathrm{A}}$ & $10.23 \pm 1.52 \mathrm{c}^{\mathrm{A}}$ \\
150 & $7.45 \pm 0.22 \mathrm{a}^{\mathrm{C}}$ & $7.63 \pm 1.55 \mathrm{a}^{\mathrm{C}}$ & $7.60 \pm 0.77 \mathrm{a}^{\mathrm{C}}$ & $9.90 \pm 0.33 \mathrm{~b}^{\mathrm{B}}$ & $10.07 \pm 0.47 \mathrm{c}^{\mathrm{B}}$ & $10.07 \pm 0.23 \mathrm{c}^{\mathrm{B}}$ \\
180 & $6.59 \pm 0.47 \mathrm{a}^{\mathrm{C}}$ & $6.68 \pm 1.63 \mathrm{a}^{\mathrm{C}}$ & $6.63 \pm 0.33 \mathrm{a}^{\mathrm{C}}$ & $9.75 \pm 0.12 \mathrm{~b}^{\mathrm{B}}$ & $9.90 \pm 0.45 \mathrm{c}^{\mathrm{B}}$ & $9.90 \pm 1.25 \mathrm{c}^{\mathrm{B}}$ \\
\hline
\end{tabular}

a,b,c The differences between the values in the same row are statistically significant $(\mathrm{p}<0.05)$. ${ }^{\mathrm{A}, \mathrm{B}, \mathrm{C}}$ The differences between the values in the same column are statistically significant $(\mathrm{p}<0.05)$.

Table 2. Changes in the number of Bifidobacterium longum in cheese samples during ripening $\log _{10}(\mathrm{cfu} / \mathrm{g})$.

\begin{tabular}{clllccc}
\hline Days/ Samples & SHPK & SHPK $+\mathrm{F}$ & SHPK+I & MKP & MKP+F & MKP+I \\
\hline 1 & $9.29 \pm 0.41 \mathrm{a}^{\mathrm{A}}$ & $9.32 \pm 0.20 \mathrm{a}^{\mathrm{A}}$ & $9.32 \pm 1.12 \mathrm{a}^{\mathrm{A}}$ & $10.37 \pm 0.04 \mathrm{~b}^{\mathrm{A}}$ & $10.45 \pm 1.12 \mathrm{~b}^{\mathrm{A}}$ & $10.44 \pm 0.08 \mathrm{~b}^{\mathrm{A}}$ \\
15 & $9.25 \pm 0.02 \mathrm{a}^{\mathrm{A}}$ & $9.31 \pm 0.18 \mathrm{a}^{\mathrm{A}}$ & $9.30 \pm 1.45 \mathrm{a}^{\mathrm{A}}$ & $10.34 \pm 0.01 \mathrm{~b}^{\mathrm{A}}$ & $10.43 \pm 1.08 \mathrm{c}^{\mathrm{A}}$ & $10.39 \pm 0.01 \mathrm{c}^{\mathrm{A}}$ \\
30 & $9.14 \pm 0.06 \mathrm{a}^{\mathrm{A}}$ & $9.26 \pm 0.43 \mathrm{a}^{\mathrm{A}}$ & $9.25 \pm 1.23 \mathrm{a}^{\mathrm{A}}$ & $10.31 \pm 0.14 \mathrm{~b}^{\mathrm{A}}$ & $10.39 \pm 1.04 \mathrm{c}^{\mathrm{A}}$ & $10.38 \pm 0.02 \mathrm{c}^{\mathrm{A}}$ \\
45 & $9.08 \pm 0.08 \mathrm{a}^{\mathrm{A}}$ & $9.20 \pm 0.73 \mathrm{a}^{\mathrm{A}}$ & $9.19 \pm 1.18 \mathrm{a}^{\mathrm{A}}$ & $10.30 \pm 0.19 \mathrm{~b}^{\mathrm{A}}$ & $10.37 \pm 1.13 \mathrm{c}^{\mathrm{A}}$ & $10.36 \pm 0.08 \mathrm{c}^{\mathrm{A}}$ \\
60 & $9.02 \pm 0.11 \mathrm{a}^{\mathrm{A}}$ & $9.16 \pm 0.13 \mathrm{a}^{\mathrm{A}}$ & $9.15 \pm 1.14 \mathrm{a}^{\mathrm{A}}$ & $10.27 \pm 0.24 \mathrm{~b}^{\mathrm{A}}$ & $10.34 \pm 1.07 \mathrm{c}^{\mathrm{A}}$ & $10.30 \pm 0.11 \mathrm{c}^{\mathrm{A}}$ \\
75 & $8.90 \pm 0.26 \mathrm{a}^{\mathrm{A}}$ & $9.03 \pm 0.40 \mathrm{a}^{\mathrm{A}}$ & $9.00 \pm 0.08 \mathrm{a}^{\mathrm{A}}$ & $10.14 \pm 0.25 \mathrm{~b}^{\mathrm{A}}$ & $10.31 \pm 0.08 \mathrm{c}^{\mathrm{A}}$ & $10.30 \pm 0.14 \mathrm{c}^{\mathrm{A}}$ \\
90 & $8.46 \pm 0.45 \mathrm{a}^{\mathrm{AB}}$ & $8.78 \pm 0.09 \mathrm{a}^{\mathrm{A}}$ & $8.78 \pm 1.16 \mathrm{a}^{\mathrm{A}}$ & $10.04 \pm 0.12 \mathrm{~b}^{\mathrm{A}}$ & $10.03 \pm 0.07 \mathrm{c}^{\mathrm{A}}$ & $10.03 \pm 0.25 \mathrm{c}^{\mathrm{A}}$ \\
120 & $8.52 \pm 0.06 \mathrm{a}^{\mathrm{A}}$ & $8.54 \pm 0.05 \mathrm{a}^{\mathrm{A}}$ & $8.52 \pm 0.01 \mathrm{a}^{\mathrm{A}}$ & $10.02 \pm 0.20 \mathrm{~b}^{\mathrm{A}}$ & $10.21 \pm 1.25 \mathrm{c}^{\mathrm{A}}$ & $10.20 \pm 0.17 \mathrm{c}^{\mathrm{A}}$ \\
150 & $7.39 \pm 0.04 \mathrm{a}^{\mathrm{B}}$ & $7.62 \pm 0.07 \mathrm{a}^{\mathrm{B}}$ & $7.61 \pm 0.09 \mathrm{a}^{\mathrm{B}}$ & $9.89 \pm 0.10 \mathrm{~b}^{\mathrm{B}}$ & $10.05 \pm 2.34 \mathrm{c}^{\mathrm{B}}$ & $10.04 \pm 0.47 \mathrm{c}^{\mathrm{B}}$ \\
180 & $6.58 \pm 0.10 \mathrm{a}^{\mathrm{C}}$ & $6.68 \pm 0.17 \mathrm{a}^{\mathrm{C}}$ & $6.67 \pm 1.23 \mathrm{a}^{\mathrm{C}}$ & $9.75 \pm 0.04 \mathrm{a}^{\mathrm{B}}$ & $9.90 \pm 1.56 \mathrm{a}^{\mathrm{B}}$ & $9.90 \pm 0.56 \mathrm{a}^{\mathrm{B}}$ \\
\hline
\end{tabular}

a,b,c The differences between the values in the same row are statistically significant $(\mathrm{p}<0.05)$. A,B,CThe differences between the values in the same column are statistically significant $(\mathrm{p}<0.05)$.

SHPK+F, SHPK+-I samples after Day 90 and in the MKP, MKP+F, MKP+I samples after Day $150(\mathrm{p}<0.05)$.

The count of B.longum in the MKP+F cheese samples was higher than that in the MKP+I samples, but this difference was statistically insignificant ( $p>0.05$ ). In these samples, it has been concluded that the count of live probiotic bacteria is much higher than the minimum therapeutic effect level $\left(10^{7} \mathrm{cfu} / \mathrm{g}\right)$ and that these cheese can be considered as probiotics. Our study has concluded that the viability of B.longum could be preserved with the microencapsulation method and the MKP and MKP+F cheese samples can be considered as probiotic cheese. Environmental factors such as $\mathrm{pH}$ change, dissolved oxygen concentration, salt penetration and concentration in pickled white cheese create an inhibitory effect on classical probiotic bacterial strains, and therefore, the related product may rapidly lose its probiotic character (Özer et al., 2009). The study by Silva et al. (2018) showed that symbiotic microencapsulation provided greater viability of $L$. acidophilus during the storage in yogurt, as well as providing functional characteristics of yogurt with added of alginate-gelatin-FOS microbeads. One of these studies conducted by Amine et al. (2014) has used encapsulated B. longum strain in the production of cheddar cheese. The study has determined that a good survival with $2 \log _{10} \mathrm{cfu} / \mathrm{mL}$ reduction after 21 days, as compared to droplet extrusion encapsulated B. longum and free cells with 3 and $4 \log _{10} \mathrm{cfu} / \mathrm{mL}$ reductions respectively.
The study by Chen et al. (2005) has examined the microencapsulation technique and the viability of probiotic bacteria such as L. acidophilus, L.casei, B. longum, B. bifidum. The study has determined that the count of B.longum and B.bifidum in free form was $8.11 \log _{10} \mathrm{cfu} / \mathrm{g}$ at the beginning and decreased to $5.89 \log _{10} \mathrm{cfu} / \mathrm{g}$ at the end of Day 16. It has also determined that the count of microencapsulated B.longum and B. bifidum was $8.01 \log _{10} \mathrm{cfu} / \mathrm{g}$ on day 1 and $7.90 \log _{10} \mathrm{cfu} / \mathrm{g}$ at the end of storage period.

\section{Changes in the total count of starter bacteria in cheese during ripening period}

The changes in the count of Lactococci in the composition of the starter culture used in the production of goat cheeses produced using probiotic culture, prebiotic + probiotic culture, microencapsulated probiotic culture and symbiotic microcapsule in our study are collectively given in Table 3.

It has been determined that the count of starter cultures at the end of 180-day ripening period in the $\mathrm{SHPK}, \mathrm{SHPK}+\mathrm{F}$, SHPK+I, MKP, MKP+F, MKP+I and K cheese samples decreased by $4 \log _{10}$ from $10^{9} \mathrm{cfu} / \mathrm{g}$ to $10^{5} \mathrm{cfu} / \mathrm{g}$. Significant decreases in the count of starter cultures have been observed in all cheese samples during the 180-day ripening period due to reasons such as salt transition from pickled to cheese mass and acidity development during the ripening period. 
Table 3. Changes in the number of starter culture in cheese samples during ripening $\log _{10}(\mathrm{cfu} / \mathrm{g})$.

\begin{tabular}{cccccccc}
\hline Days/Samples & SHPK & SHPK $+\mathrm{F}$ & SHPK $+\mathrm{I}$ & MKP & MKP+F & MKP+I \\
\hline 1 & $9.3 \pm 0.88 \mathrm{a}^{\mathrm{A}}$ & $9.33 \pm 0.11 \mathrm{a}^{\mathrm{A}}$ & $9.32 \pm 0.09 \mathrm{a}^{\mathrm{A}}$ & $9.48 \pm 0.91 \mathrm{ab}^{\mathrm{A}}$ & $9.56 \pm 1.04 \mathrm{ab}^{\mathrm{A}}$ & $9.51 \pm 0.03 \mathrm{ab}^{\mathrm{A}}$ & $9.47 \pm 0.06 \mathrm{a}^{\mathrm{A}}$ \\
15 & $9.22 \pm 0.12 \mathrm{a}^{\mathrm{A}}$ & $9.31 \pm 0.53 \mathrm{a}^{\mathrm{A}}$ & $7.30 \pm 0.02 \mathrm{a}^{\mathrm{A}}$ & $9.32 \pm 0.07 \mathrm{~b}^{\mathrm{A}}$ & $9.54 \pm 0.03 \mathrm{a}^{\mathrm{A}}$ & $9.53 \pm 0.09 \mathrm{a}^{\mathrm{A}}$ & $9.61 \pm 0.42 \mathrm{a}^{\mathrm{A}}$ \\
30 & $8.79 \pm 0.08 \mathrm{a}^{\mathrm{B}}$ & $9.12 \pm 0.33 \mathrm{a}^{\mathrm{A}}$ & $9.11 \pm 0.15 \mathrm{a}^{\mathrm{A}}$ & $9.16 \pm 0.05 \mathrm{~b}^{\mathrm{A}}$ & $9.48 \pm 0.09 \mathrm{a}^{\mathrm{A}}$ & $9.51 \pm 0.07 \mathrm{a}^{\mathrm{A}}$ & $9.55 \pm 0.63 \mathrm{a}^{\mathrm{A}}$ \\
45 & $8.74 \pm 0.02 \mathrm{a}^{\mathrm{B}}$ & $8.87 \pm 0.24 \mathrm{ab}^{\mathrm{B}}$ & $8.87 \pm 0.46 \mathrm{ab}^{\mathrm{B}}$ & $9.02 \pm 1.12 \mathrm{a}^{\mathrm{A}}$ & $9.39 \pm 0.07 \mathrm{a}^{\mathrm{A}}$ & $9.36 \pm 0.19 \mathrm{a}^{\mathrm{A}}$ & $9.41 \pm 0.40 \mathrm{a}^{\mathrm{A}}$ \\
60 & $8.68 \pm 0.14 \mathrm{a}^{\mathrm{B}}$ & $8.82 \pm 0.47 \mathrm{~b}^{\mathrm{B}}$ & $8.81 \pm 0.22 \mathrm{~b}^{\mathrm{B}}$ & $9.28 \pm 1.09 \mathrm{a}^{\mathrm{A}}$ & $9.29 \pm 1.16 \mathrm{a}^{\mathrm{A}}$ & $9.26 \pm 1.24 \mathrm{a}^{\mathrm{A}}$ & $9.37 \pm 0.51 \mathrm{a}^{\mathrm{A}}$ \\
75 & $8.45 \pm 0.36 \mathrm{a}^{\mathrm{B}}$ & $8.67 \pm 0.86 \mathrm{a}^{\mathrm{B}}$ & $8.67 \pm 0.55 \mathrm{a}^{\mathrm{B}}$ & $8.80 \pm 1.06 \mathrm{~b}^{\mathrm{B}}$ & $8.81 \pm 0.08 \mathrm{a}^{\mathrm{B}}$ & $8.80 \pm 1.10 \mathrm{a}^{\mathrm{B}}$ & $8.40 \pm 0.60 \mathrm{a}^{\mathrm{B}}$ \\
90 & $7.67 \pm 0.87 \mathrm{a}^{\mathrm{C}}$ & $7.70 \pm 0.33 \mathrm{a}^{\mathrm{C}}$ & $7.70 \pm 0.72 \mathrm{a}^{\mathrm{C}}$ & $7.69 \pm 0.23 \mathrm{a}^{\mathrm{B}}$ & $7.68 \pm 0.03 \mathrm{a}^{\mathrm{B}}$ & $7.68 \pm 0.05 \mathrm{a}^{\mathrm{B}}$ & $8.68 \pm 0.89 \mathrm{a}^{\mathrm{B}}$ \\
120 & $7.41 \pm 0.54 \mathrm{a}^{\mathrm{C}}$ & $7.40 \pm 0.29 \mathrm{a}^{\mathrm{C}}$ & $7.37 \pm 0.49 \mathrm{a}^{\mathrm{C}}$ & $7.35 \pm 0.31 \mathrm{a}^{\mathrm{B}}$ & $7.40 \pm 0.19 \mathrm{a}^{\mathrm{B}}$ & $7.39 \pm 0.87 \mathrm{a}^{\mathrm{B}}$ & $7.45 \pm 0.71 \mathrm{a}^{\mathrm{B}}$ \\
150 & $6.61 \pm 0.41 \mathrm{a}^{\mathrm{C}}$ & $6.62 \pm 0.21 \mathrm{a}^{\mathrm{C}}$ & $6.61 \pm 0.24 \mathrm{a}^{\mathrm{C}}$ & $6.53 \pm 0.27 \mathrm{~b}^{\mathrm{C}}$ & $6.54 \pm 0.57 \mathrm{~b}^{\mathrm{C}}$ & $6.53 \pm 0.53 \mathrm{~b}^{\mathrm{C}}$ & $6.63 \pm 0.43 \mathrm{a}^{\mathrm{C}}$ \\
180 & $5.60 \pm 0.12 \mathrm{a}^{\mathrm{D}}$ & $5.61 \pm 0.17 \mathrm{ab}^{\mathrm{D}}$ & $5.60 \pm 0.83 \mathrm{ab}^{\mathrm{D}}$ & $5.48 \pm 1.23 \mathrm{~b}^{\mathrm{C}}$ & $5.51 \pm 0.63 \mathrm{~b}^{\mathrm{C}}$ & $5.51 \pm 0.21 \mathrm{~b}^{\mathrm{C}}$ & $5.62 \pm 0.54 \mathrm{a}^{\mathrm{C}}$ \\
\hline
\end{tabular}

a,b.c The differences between the values in the same row are statistically significant $(\mathrm{p}<0.05)$. ${ }^{\mathrm{A} B, \mathrm{C}}$ The differences between the values in the same column are statistically significant $(\mathrm{p}<0.05)$.

The analyzes made in our research have shown that there were small differences in all cheese samples due to vaccination, inoculation rate and a decrease was observed at the end of 180day ripening period. The analysis of variance has revealed that the difference between the samples was statistically insignificant $(p>0.05)$ and the use of probiotic bacteria as a support culture in cheese production had no effect on the development of the starter Lactococci in the cheese matrix. In addition, the effect of the ripening process on starter bacteria was significant $(\mathrm{p}<0.05)$.

\section{Conclusion}

Successful results have been obtained in the protection of probiotic microorganisms in foods against the negative effects of environmental factors by microencapsulation method. As a result of this study carried out with the idea of benefiting from this technology, which is successfully applied in different dairy products, in the production of pickled white goat cheese. it has been determined that the viability of $L$. paracase $i$ and B. longum is preserved with the microencapsulation technique, and the viability of probiotic bacteria is preserved at a higher level in cheese samples obtained with the addition of prebiotics to microencapsules.

In conclusion, the viability of probiotic microorganisms when used in cheese samples in free form was found to be 1-1.5 logarithmic units lower than that when they were encapsulated. This case continued throughout the entire ripening period in our study and was clearly revealed at the end of the storage process, especially in cheese produced using probiotic cultures. The result that the microencapsulation technique used in our study significantly increases the viability levels of probiotic microorganisms has been proven by many researchers (Özer et al., 2009; Liu et al., 2017; Ningtyas et al., 2019; Siang et al., 2019).

Considering that probiotic microorganisms are available above the minimum therapeutic effect value in grams $\left(10^{9} \mathrm{cfu}\right)$ of cheese samples containing microcapsules, the MKP, MKP+I and $\mathrm{MKP}+\mathrm{F}$ cheese samples produced by us in our study can be considered as "Probiotic Goat Cheese" or "Functional Goat Cheese" based on the international standards. Based on this, it is considered that consuming an amount of $100 \mathrm{~g}$ or more per day from the cheese samples obtained in our study may be sufficient to demonstrate the probiotic effect.

\section{Acknowledgements}

This work was supported by the Scientific and Technological Research Council of Turkey (TÜBİTAK), Grant No: TÜBİTAK TOVAG 1080039.

\section{References}

Amine, K. M., Champagne, C. P., Raymond, Y., St-Gelais, D., Britten, M., Fustier, P., Salmieri, S., \& Lacroix, M. (2014). Survival of microencapsulated Bifidobacterium longum in Cheddar cheese during production and storage. Food Control, 37, 193-199. http:// dx.doi.org/10.1016/j.foodcont.2013.09.030.

Čakarević, J., Šeregelj, V., Tumbas Šaponjac, V., Ćetković, G., Čanadanović Brunet, J., Popović, S., Kostić, M. H., \& Popović, L. (2020). Encapsulation of beetroot juice: a study on the application of pumpkin oil cake protein as new carrier agent. Journal of Microencapsulation, 37(2), 121-133. http://dx.doi.org/10.1080/02 652048.2019.1705408. PMid:31835967.

Castro, J. M., Tornadijo, M. E., Fresno, J. M., \& Sandoval, H. (2015). Biocheese: a food probiotic carrier. BioMed Research International, 2015, 1-11. http://dx.doi.org/10.1155/2015/723056. PMid:25802862.

Chaudhary, H. J., \& Patel, A. R. (2019). Microencapsulation technology to enhance the viability of probiotic bacteria in fermented foods. International Journal of Fermented Food, 8(2), 63-72. http://dx.doi. org/10.30954/2321-712X.02.2019.1.

Chen, K. N., Chen, M., \& Lin, C. W. (2006). Optimal combination of the encapsulating materials for probiotic microcapsules and its experimental verication (R1). Journal of Food Engineering, 76(3), 313-320. http://dx.doi.org/10.1016/j.jfoodeng.2005.05.036.

Chen, K. N., Chen, M., Lin, C. W., \& Chiu, H. Y. (2005). Optimization of incorporated prebiotics as coating materials for probiotic microencapsulation. Journal of Food Science, 70(5), 260-266. http:// dx.doi.org/10.1111/j.1365-2621.2005.tb09981.x.

Evangelia, Z., Dimitrios, K., Theophilos, M., \& Emmanuel, A. (2016). the effect of probiotic lactic acid bacteria on the characteristics of Galotyri Cheese. International Journal of Clinical Nutrition \& Dietetics, 2(1), 114. http://dx.doi.org/10.15344/2456-8171/2016/114.

Fangmeier, M., Kemerich, G. T., Machado, B. L., Maciel, M. J., \& Volken de Souza, C. F. (2019). Effects of cow, goat, and buffalo milk on the characteristics of cream cheese with whey retention. Food Science and Technology, 39(Suppl. 1), 122-128. http://dx.doi.org/10.1590/ fst.39317. 
Gardiner, G. E., Bouchier, P., O'Sullivan, E., Kelly, J., Collins, J. K., Fitzgerald, G., Ross, R. P., \& Stanton, C. (2002). A spray-dried culture for probiotic Cheddar cheese manufacture. International Dairy Journal, 12(9), 749-756. http://dx.doi.org/10.1016/S09586946(02)00072-9.

Guarner, F. (2017). WGO Global Guideline Probiotics and prebiotics (pp. 1-35). Milwaukee: World Gastroenterology Organisation.

Herman-Lara, E., Bolívar-Moreno, D., Toledo-Lopez, V. M., CuevasGlory, L. F., Lope-Navarrete, M. C., Barron-Zambrano, J. A., DíazRivera, P., \& Ramírez-Rıvera, E. J. (2019). Minerals multi-element analysis and its relationship with geographical origin of artisanal Mexican goat cheeses. Food Science and Technology, 39(2, Suppl 2), 517-525. http://dx.doi.org/10.1590/fst.23918.

International Dairy Federation - IDF. (2008). Physiological and functional properties of probiotics (Bulletin of International Dairy Federation, No. 429/2008). Brussels: IDF.

Liu, L., Chen, P., Zhao, W., Li, X., Wang, H., \& Qu, X. (2017). Effect of microencapsulation with the Maillard reaction products of whey proteins and isomaltooligosaccharide on the survival rate of Lactobacillus rhamnosus in white brined cheese. Food Control, 79, 44-49. http://dx.doi.org/10.1016/j.foodcont.2017.03.016.

Lucatto, J. N., Sılva-Buzanello, R. A., Mendonça, S. N. T. G., Lazarotto, T. C., Sanchez, J. L., Bona, E., \& Drunkler, D. A. (2020). Performance of different microbial cultures in potentially probiotic and prebiotic yoghurts from cow and goat milks. International Journal of Dairy Technology, 73(1), 144-156. http://dx.doi.org/10.1111/1471-0307.12655.

Madureira, A. R., Pereira, C. I., Truszkowska, K., Gomes, A. M., Pintado, M. E., \& Malcata, F. X. (2005). Survival of probiotic bacteria in a whey cheese vector submitted to environmental conditions prevailing in the gastrointestinal tract. International Dairy Journal, 15(6-9), 921-927. http://dx.doi.org/10.1016/j.idairyj.2004.08.025.

Menezes, M. F. S. C., Silva, T. M., Etchepare, M. A., Fonseca, B. S., Sonza, V. P., Codevilla, C. F., Barin, J. S., Silva, C. B., \& Menezes, C. R. (2019). Improvement of the viability of probiotics (Lactobacillus acidophilus) by multilayer encapsulation. Ciência Rural, Santa Maria, 49(9), e20181020. http://dx.doi.org/10.1590/0103-8478cr20181020.

Moraes, G. M. D., Santos, K. M. O., Barcelos, S. C., Lopes, S. A., \& Egito, A. S. (2018). Potentially probiotic goat cheese produced with autochthonous adjunct culture of Lactobacillus mucosae, microbiological, physicochemical and sensory attributes. Lebensmittel-Wissenschaft + Technologie, 94, 57-63. http://dx.doi.org/10.1016/j.lwt.2018.04.028.

Ningtyas, D. W., Bhandari, B., Bansal, N., \& Prakash, S. (2019). The viability of probiotic Lactobacillus rhamnosus (non-encapsulated andencapsulated) in functional reduced-fat cream cheese and its textural properties during storage. Food Control, 100, 8-16. http:// dx.doi.org/10.1016/j.foodcont.2018.12.048.

Özer, B., Kirmaci, H. A., Şenel, E., Atamer, M., \& Hayaloğlu, A. (2009). Improving the viability of Bifidobacterium bifidum BB12 and Lactobacillus acidophilus LA- 5 in white-brined cheese by microencapsulation. International Dairy Journal, 19(1), 22-29. http:// dx.doi.org/10.1016/j.idairyj.2008.07.001.
Pivetta, F. P., Sılva, M. N., Tagliapietra, B. L., \& Richards, N. S. S. (2020). Addition of green banana biomass as partial substitute for fat and encapsulated Lactobacillus acidophilus in requeijão cremoso processed cheese. Food Science and Technology, 40(2), 451-457. http://dx.doi. org/10.1590/fst.03919.

Rama, G. R., Führ, A. J., Silva, J. A. B. S., Gennari, A., Giroldi, M., Goettert, M. I., \& Souza, C. F. V. (2020). Encapsulation of Lactobacillus spp. using bovine and buffalo cheese whey and their application in orange juice. 3 Biotech, 10(6), 263. http://dx.doi.org/10.1007/ s13205-020-02255-9. PMid:32509496.

Ranadheera, C. S., Evans, C. A., Baines, S. K., Balthazar, C. F., Cruz, A. G., Esmerino, E. A., Freitas, M. Q., Pimentel, T. C., Wittwer, A. E., Naumovski, N., Graça, J. S., Sant'Ana, A. S., Ajlouni, S., \& Vasiljevic, T. (2019). Probiotics in goat milk products: delivery capacity and ability to improve sensory attributes. Comprehensive Reviews in Food Science and Food Safety, 18(4), 867-882. http://dx.doi. org/10.1111/1541-4337.12447.

Ranadheera, C. S., Naumovski, N., \& Ajlouni, S. (2018). Non-bovine milk products as emerging probiotic carriers: recent developments and innovations. Current Opinion in Food Science, 22, 109-114. http://dx.doi.org/10.1016/j.cofs.2018.02.010.

Rezaei, A., Fathi, M., \& Mahdi Jafari, S. (2019). Nanoencapsulation of hydrophobic and low-soluble food bioactive compounds within different nanocarriers. Food Hydrocolloids, 88, 146-162. http:// dx.doi.org/10.1016/j.foodhyd.2018.10.003.

Samedi, L., \& Charles, A. L. (2019). Viability of 4 probiotic bacteria microencapsulated with arrowroot starch in the simulated Gastrointestinal Tract (GIT) and yoghurt. Foods, 8(5), 175. http:// dx.doi.org/10.3390/foods8050175. PMid:31137631.

Sanders, M. E., Merenstein, D., Merrifield, C. A., \& Hutkins, R. (2018). Probiotics for human use. Nutrition Bulletin, 43(3), 212-225. http:// dx.doi.org/10.1111/nbu.12334.

Shori, A., Aboulfazli, F., \& Baba, A. S. (2018). Viability of probiotics in dairy products: a review focusing on yogurt. In A. Datta, M. Fakruddin, H. M. N. Iqbal \& J. Abraham (Eds.), Ice cream, and cheese advances in biotechnology (Chap. 6, pp. 1-26). Las Vegas: Open Access eBooks.

Siang, S. C., Wai, L. K., Lin, N. K., \& Phing, P. L. (2019). Effect of added prebiotic (Isomalto-oligosaccharide) and coating of beads on the survival of microencapsulated Lactobacillus rhamnosus GG. Food Science and Technology, 39(Suppl. 2), 601-609. http://dx.doi. org/10.1590/fst.27518.

Silva, K. C. G., Cezarino, C., Michelon, M., \& Sato, A. C. K. (2018). Symbiotic microencapsulation to enhance Lactobacillus acidophilus survival. Lebensmittel-Wissenschaft + Technologie, 89, 503-509. http:// dx.doi.org/10.1016/j.lwt.2017.11.026.

Sipahioğlu, O., Alvarez, V. B., \& Solano-Lopez, C. (1999). Structure, physico-chemical and sensory properties of feta cheese made tapioca starch and lecithin as fat mimetics. International Dairy Journal, 9(11), 783-789. http://dx.doi.org/10.1016/S0958-6946(99)00150-8. 